\title{
Industrial pollution, spatial stigma and economic decline: the case of Asopos river basin through the lens of local small business owners
}

Article

Accepted Version

Skouloudis, A., Jones, N., Roumeliotis, S., Issac, D., Greig, A. and Evangelinos, K. (2017) Industrial pollution, spatial stigma and economic decline: the case of Asopos river basin through the lens of local small business owners. Journal of

Environmental Planning and Management, 60 (9). pp. 15751600. ISSN 0964-0568 doi:

https://doi.org/10.1080/09640568.2016.1243519 Available at https://centaur.reading.ac.uk/70220/

It is advisable to refer to the publisher's version if you intend to cite from the work. See Guidance on citing.

Published version at: http://dx.doi.org/10.1080/09640568.2016.1243519

To link to this article DOI: http://dx.doi.org/10.1080/09640568.2016.1243519

Publisher: Taylor and Francis

All outputs in CentAUR are protected by Intellectual Property Rights law, including copyright law. Copyright and IPR is retained by the creators or other copyright holders. Terms and conditions for use of this material are defined in the End User Agreement. 


\section{www.reading.ac.uk/centaur}

\section{CentAUR}

Central Archive at the University of Reading

Reading's research outputs online 


\section{Journal of Environmental Routledge Planning and Management 1 Tyylors francis croup}

\section{Industrial pollution, spatial stigma and economic decline: The case of Asopos river basin through the lens of local small business owners}

\begin{tabular}{|r|l|}
\hline Journal: & Journal of Environmental Planning and Management \\
\hline Manuscript ID & CJEP-2015-0175.R2 \\
\hline Manuscript Type: & Research Article \\
\hline Keywords: & $\begin{array}{l}\text { Environmental degradation, industrial pollution, qualitative survey, small } \\
\text { business, Asopos river }\end{array}$ \\
\hline Abstract: & $\begin{array}{l}\text { This paper explores the notion of environmentally-induced spatial stigma } \\
\text { through an analysis of data from interviews across public attitudes to } \\
\text { pollution within the Asopos river basin in central Greece. The study focuses } \\
\text { on the perceptions and beliefs of a sector of the community likely to be } \\
\text { directly and negatively affected by stigma, that is small business owners in } \\
\text { the tourism and hospitality sector. The qualitative analysis explores } \\
\text { awareness and viewpoints on environmental degradation and water quality } \\
\text { within the local context, implications on the local economy and the } \\
\text { individual's own enterprise, views on industrial environmental management } \\
\text { as well as corporate responsibility and future prospects on the } \\
\text { environmental problem of Asopos. Findings reveal a noticeable variation in } \\
\text { views on industrial pollution and ecosystem deterioration among the } \\
\text { respondents but overall a strong environmentally-induced stigmatization of } \\
\text { the area. }\end{array}$ \\
\hline
\end{tabular}

\section{SCHOLARONE"}

Manuscripts 


\title{
Industrial pollution, spatial stigma and economic decline: The case of Asopos river basin through the lens of local small business owners
}

\begin{abstract}
This paper explores the notion of environmentally-induced spatial stigma through an analysis of data from interviews across public attitudes to pollution within the Asopos river basin in central Greece. The area has a 40 year plus history of legal and illicit industrial waste disposal and public debate on the associated environmental degradation. The study focuses on the perceptions and beliefs of a sector of the community likely to be directly and negatively affected by stigma, that is small business owners in the tourism and hospitality sector. The qualitative analysis explores awareness and viewpoints on environmental degradation and water quality within the local context, implications on the local economy and the individual's own enterprise, views on industrial environmental management as well as corporate responsibility and future prospects on the environmental problem of Asopos. Findings reveal a noticeable variation in views on industrial pollution and ecosystem deterioration among the respondents but overall a strong environmentally-induced stigmatization of the area. They also uncover an information asymmetry and lack of credible commitment by government bodies and industry members in disclosing accurate information, a situation likely to increase speculation and uncertainty within the community. The paper concludes by addressing implications of the findings to policy-making and managerial considerations along with future research perspectives which aim to increase considerations of sustainability aspects for local development.
\end{abstract}

Keywords: Environmental degradation, spatial stigma, industrial pollution, small business, qualitative survey, Asopos river, local sustainability. 


\section{Introduction}

Several studies demonstrate that industrial pollution results in multiple effects at a local scale which extend beyond the disruption of natural resources, the deterioration of biophysical functions and depreciation of ecosystem services (e.g. Wakefield and Elliot, 2000; Moffatt and Pless-Mulloli, 2003; Burningham and Thrush, 2004; Castán Broto et al., 2010; Colocousis, 2012). The reduction in environmental quality can alter and discredit the intrinsic characteristics of a distinct locale and stigmatize the overall image, reputation and identity of the area. This has important policy making implications as it infers that scientific and technological efforts to improve the physical environment will not, on their own, be enough to secure wider community regeneration.

The notion of environmentally-induced stigma can indicate an inherent property of (discovered or anticipated) changes to a place, a local community or even a local product that is linked with the exposure to a toxic substance (Edelstein, 1987: 21). Furthermore, areas marked with environmental stigma can experience multidimensional disruption and marginalization which eventually aggravate territorial, socioeconomic and health inequalities (Brown and Mikkelsen, 1990; Satterfield, 2000; Edelstein, 2004; Ellerbusch, 2006; Noonan et al., 2007; Keene and Padilla, 2014), social exclusion and economic decline (Satterfield, 2000; Hayden, 2000; Ellerbusch, 2006; Noonan et al., 2007; Erickson et al., 2008). These socioeconomic features are strongly linked to the identity of place and when stigmatization occurs, these place-based characteristics also take on negative associations (Wester-Herber, 2004), creating what has been called 'spatial stigma'.

Current literature highlights the contingent nature of community concerns over environmental degradation and related landscape transformations due to industrial activities as well as underlying coping strategies developed and employed in order to deal with the loss of quality of life. In this respect, Parkhill et al. (2014) point out three key lenses in which stigmatization has been contextualized in current literature in relation to place-based identity and industrial infrastructures. The first is found in studies where stigma has been identified in places where socio-environmentally risky facilities are sited. The second refers to evidence of stigmatization being resisted and/or rejected by local residents who are not acknowledge negative attributes ascribed to their community. Third, it has been suggested that due to the contribution of industrial activity to local economic growth and stability, environmental pollution and the consequent notion of stigma can be disregarded and suppressed.

Drawing upon the work of these scholars we pursued for place-based interpretations, beliefs and aspirations related to socioeconomic implications of living close to a persistent industrial point-source pollution. We chose as a case study the Asopos river area in Greece which has been identified as an area facing an environmental crises due to long-term industrial pollution (Tentes and Damigos, 2012). The specific river has been receiving effluent and solid wastes from industries located within its catchment for over 45 years resulting to a gradual environmental degradation of the water basin and the surrounding area. The paper describes the results of a qualitative social research aiming to highlight some informative points on the attitudes and perceptions of local business owners located at the wider area of the river's delta. It addresses issues surrounding the impact of environmental stigma on local development and point out differing views on and a typology of representations regarding place-based identity. 


\section{Spatial stigma and environmental degradation}

Stigma theory can be traced back to the work of Erving Goffman $(1963$, p.9) who described the concept as "the situation of the individual who is disqualified from full social acceptance". Since then, scholars have expanded their references to stigmatization to include products, technologies or geographic areas (Gregory et al., 1995). Geographical areas have been identified as socially constructed and dynamically evolving "living systems in constant evolution with a significant symbolic component" where "humans engage with the landscape through daily practices, rather than by detached visual contemplation" (Castan Broto et al., 2007: p. 483). Kasperson et al. (2003) stress that negative labels may drastically alter the identity of a place so that it is viewed as tainted and discredited both by residents and by outsiders, damaging its reputation and image. In this respect, Gregory et al. (1995) note that stigmatized places often share common features such as the following:

1. The stigma is generated by a hazard perceived to carry a high negative risk;

2. The natural order of things is perceived to be tarnished, discredited and/or blemished;

3. Impacts are perceived to be inequitably distributed across demographic groups or geographic areas;

4. There is scientific uncertainty over their potential health and environmental magnitude or persistence over time; and

5. The effective management of the stigmatization hazard is questionable giving rise to concerns about competence, conflicts of interest, or a failure to apply proper values and precautions.

A number of scholars provide geographically- and pollutant-specific case studies, employing a variety of qualitative and mixed methods approaches exploring the links between local socioeconomic characteristics, environmental degradation and stigmatization. In this context, Bush et al. (2001) offer qualitative findings on how hazardous industrial activity can affect the identity of an area and its inhabitants. Likewise, Howel et al. (2003) investigate through a questionnaire-based survey public perceptions in terms of individual and locality factors and indicate considerable variation among residents views according to their proximity to the polluting industrial facilities. The complexity of residents associations between the physical impact of pollution and socioeconomic factors is also emphasized by Bickerstaff and Walker (2003) who review developments in the research in particular relating to community challenges to air pollution. Moffatt and Pless-Mulloli (2003) report qualitative evidence on environmental and health concerns of parents living close to opencast coal mines and identify parental risk perceptions in relation to children's asthma status. In a similar vein, Tilt (2006) offers empirical evidence on how community members in an industrialized township interpret environmental risks related to industrial pollution. Colocousis (2012) conducts an ethnographic study to a community once dependent on the pulp and paper industry and identifies the negative environmental image as a concrete obstacle to redevelopment of the deindustrialized area. Wester-Herber's review paper (2004) points out the need to include local attachment to a specific geographical place in the debate of industrial risks and delineates how aspects of place-identity can be negatively affected when changes are made to a landscape by the introduction of high-risk industrial ventures. In a similar perspective, Keene and Padilla (2014) develop a conceptual framework connecting spatial stigma to health concerns and stress that spatial stigma is likely to be a critical and understudied aspect through which disadvantaged places contribute to various 
physical or health outcomes. Finally, Rahardyan et al. (2006) and Achillas et al. (2011) examine the social acceptance and residential perceptions among members of local communities regarding the development and operation of solid waste management facilities.

\subsection{Place attachment and identity}

Place attachment and its role in shaping individual identities has been an issue which has attracted considerable attention under a multidisciplinary scope and focus (Kyle et al., 2004; Stedman and Hammer 2006). The significance of space and place to individual understandings of particularities of spatial context has been of interest to scholars spanning from human geography and science and technology studies to environmental sociology and environmental psychology. Such studies have emphasized on the positive relationship between the sense of emotional investment in a place (i.e. place attachment) and social identities (Manzo, 2005). Nevertheless, Irwin (2001, p.175) relatively asserts that '(...) environmental problems do not sit apart from everyday life (as if they were discrete from other issues and concerns) but instead are accommodated within (and help shape) the social construction of local reality'. Indeed, comparatively fewer studies have explored through an interpretive perspective of how polluted places or landscapes undergoing radical physical changes are shaping social understandings of the surrounding setting. It is not until recently researchers have sought to provide a better understanding of how individuals perceive and reflect on their experiences of living in close proximity to noxious industrial facilities and underlying environmental risks (e.g. Howel et al. 2002; Bickerstaff 2004; Burningham and Thrush 2004; Boholm and Lofstedt 2004; Masuda and Garvin 2006). These scholars provide supporting evidence denoting that under such transformative environmental conditions, the identity-place relationships can be redefined with adaptive responses generated and a new sense of place to be developed (Simmons and Walker, 2005; Hopkins and Dixon, 2006).

Previous research finds that those living close to industrial plants and facilities develop distinct coping strategies in order to address the burden of potentially harmful environmental externalities that occur in the area. In La Hague (France), Zonabend (1993) finds that local residents living in the vicinity of a nuclear industry unfold a discourse of safety with concerns of environmental risks to be either silenced or diminished. Focusing on the proposed siting of two landfills in Ontario (Canada), Wakefield and Elliot (2000) identify an array of coping approaches in response to concerns experienced - pragmatic acceptance, sustained optimism, cynical pessimism or radical engagement - while the sense of powerlessness, according to the authors, can lead to either a consecutive or a concurrent usage of multiple coping perspectives. Baxter and Lee (2004) examine the perceptions of residents from the Swan Hills (Canada), regarding a local facility treating hazardous wastes and indicate an emphasis on the related economic benefits as well as skepticism over the negative perceptions of outsiders which are regarded as threat. In this respect, Burningham and Thrush $(2001 ; 2004)$ argue that residents of disadvantaged communities can perceive outsiders' descriptions of their place as offensive, especially when the area is portrayed as "polluted" while the local industry may be "defended" as part of local life and an integral part of the landscape. In New Caledonia, Horowitz (2010) studies a multinational mining project under the scope of the reactions of primary stakeholder groups to its operation and stresses that culturally-informed expectations of long-term social relationships as well as the reciprocal power these entailed, and concerns about long-term economic security, encapsulated a pivotal role in determining their attitudes and evaluation of the project. Castán Broto et al. (2010) and Castán Broto (2012; 
2013) study the socioeconomic impacts of coal ash disposal sites in Tuzla (Bosnia), offering qualitative evidence of the relationship between identity and place among residents living in the area while highlighting conflicting positions related to land contamination due to coal ash disposal: one based on expert knowledge and relying on a distributed approach to the attribution of responsibilities to pollution, and another one expressing experiential understanding of pollution and attributed direct responsibilities to the local industry. Cavazza and Rubichi (2014) suggest a typology of viewpoints of citizens of Modena (Italy), with regards to a local waste processing facility and present distinct social representations of environmental nuisance from industrial activity which are mainly anchored to psychological principles such as the sense of self-efficacy or trust in the local authorities. Likewise, in the context of a petrochemical complex located in Castellon (Spain), Lopez-Navarro et al. (2016) analyze how residents' cognitive appraisal of economic and environmental aspects contribute to their affective responses, and how both cognitive and affective parameters jointly shape their behavioral intentions.

\section{Methods and data collection}

\subsection{The research area}

The above issues were explored applying a case study approach (Eisenhardt, 1989; Yin, 2003) focusing on the Asopos River basin, situated in Viotia and Attica prefectures in Greece, which has been receiving the legal and illegal effluent and solid wastes from industrial plants and facilities located within its catchment for over 45 years. In 1969, under a presidential decree, incentives were provided to industries to relocate their facilities from Athens to Viotia leading to the creation of an unofficial industrial zone. The river was also designated by the Regional Authorities (Prefectures of Attica and Viotia) as a 'receiver of industrial sewage'. However, the industrial zone and its discharges were both poorly planned and poorly monitored and in 1979 the situation was aggravated further when additional permissions were given to industrial activities that were formerly forbidden. The transposition of the 2000 European Water Framework Directive (WFD) (EU, 2000) into Greek national legislation in 2003 (MoEPPW, 2003) should have marked a turning point in the unregulated pollution of the catchment and there is some evidence that this was the case. For example, between 2004 and 2009, 4.3 million euros in environmental fines for non-compliance with environmental laws and regulations were imposed on 163 industries operating in the area (Laoudi et al., 2011). However, a strategic approach to the management of the catchment was still absent, and the creation and implementation of a Management Plan and Monitoring Programme was substantially delayed. In 2007, tests of groundwater samples revealed high levels of highly toxic arsenic and hexavalent chromium $\mathrm{Cr}(\mathrm{VI})$, chemicals used in various manufacturing activities (Vasilatos et al., 2008).

It was not until 2010, when the situation was described as an 'environmental crisis' (Tentes and Damigos, 2012), that a substantial response by the State took place, namely through the legislation "Establishment of Environmental Quality Standards in Asopos River and Emission Limit Values for Liquid Industrial Wastes in Asopos RB"1. This finally rescinded the outdated provisions which allowed industry to dispose of its toxic waste into the river and groundwater. Further, this legislation made industry accountable for the costs of water and soil analysis to prove compliance with European legislation, in line with the 'polluter pays principle' embedded within the WFD. Nevertheless, little progress has been made in averting the situation in the river basin leading, in November 2015, Greece's Council of State to order apposite governmental bodies to take immediate actions to tackle high 
pollution levels following an appeal by a group of 85 residents of settlements of the greater area where the river flows into the South Euboean Gulf ${ }^{2}$.

Approximately, 350 industrial (primarily small and medium-sized enterprises SMEs) mainly within the textile, metal finishing, chemical, food, fertilizer, paint, tannery and pharmaceutical sectors operate in the industrial area of OinofytaShimatari (Massoura, 2008; Loizidou, 2009). Tables 1 and 2 indicate the distribution of industrial units per sector and main industrial pollutants $(\mathrm{kg} /$ day) linked to these activities respectively. Table 1 reveals that the most important industrial activities are those pertaining to metallurgy, followed by chemical industries and the food and beverages industries. In this respect, Loizidou (2009) indicates that the main flow of produced industrial wastes presented in Table 2 is generated primarily from the textile and leather $(25 \%)$, metallurgy-related industries $(21 \%)$ and the food and drink industrial activities $(30 \%)$.

Table 1: Distribution of the industrial activities operating in the area; Source: Loizidou (2009)

\begin{tabular}{|l|c|}
\hline Industrial activity & $\begin{array}{c}\text { Number of } \\
\text { industrial units }\end{array}$ \\
\hline Metallurgical industries & 96 \\
\hline Chemical industries & 77 \\
\hline Food and drink industries & 41 \\
\hline Warehouse facilities & 26 \\
\hline Non metallic mineral industries & 20 \\
\hline Textile \& leather industries & 20 \\
\hline Pulp, paper \& printing industries & 17 \\
\hline Woodworking industries & 15 \\
\hline Livestock farms & 11 \\
\hline Commercial-trading industries & 9 \\
\hline Other industrial activities & 46 \\
\hline Recently ceased operation & 28 \\
\hline Total & $\mathbf{3 5 0}$ \\
\hline
\end{tabular}

Table 2: Main industrial pollutants found in the Asopos river basin; Source: Loizidou (2009)

\begin{tabular}{|l|c|}
\hline Pollutant & kg/day \\
\hline BOD & 203.8 \\
\hline $\mathrm{COD}$ & 6279 \\
\hline $\mathrm{SS}$ & 2275 \\
\hline Fats & 765.5 \\
\hline $\mathrm{MBAS}$ & 12 \\
\hline $\mathrm{NO}_{3}{ }^{-}$ & 46.95 \\
\hline $\mathrm{PO}_{4}{ }^{-3}$ & 13.86 \\
\hline $\mathrm{SO}_{4}{ }^{-2}$ & 2.774 \\
\hline $\mathrm{CN}^{-}$ & 0.25 \\
\hline $\mathrm{Phenols}$ & 16.66 \\
\hline $\mathrm{AI}$ & 3.52 \\
\hline $\mathrm{Fe}$ & 5.38 \\
\hline $\mathrm{Cr}$ & 4.3 \\
\hline $\mathrm{Cr}$ & 0.00 \\
\hline $\mathrm{Cu}$ & 2.94 \\
\hline $\mathrm{Cd}$ & 0.35 \\
\hline $\mathrm{Pb}$ & 1.71 \\
\hline $\mathrm{Ni}$ & 42.27 \\
\hline $\mathrm{Zn}$ & 2.11 \\
\hline
\end{tabular}


Tentes and Damigos (2012) demonstrate that current residents are very aware of the pollution which surrounds them $(70 \%$ of their respondents acknowledged that the local environment was 'very bad), the cause of this pollution ( $94 \%$ identified local industries as the main cause of the pollution) and the impacts this was having on the environment (only 18\% would drink the local water), their health $(87 \%$ felt public health was being damaged) and the local economy (95\% felt there were negative economic impacts). In conclusion, Tentes and Damigos (2012) assert that "the river basin has foregone any ability to provide services to both humans and the ecosystem and has suffered a total loss of value" (p.1), equating to a loss of natural capital of between 7-9.3 million euros.

The pollution of the Asopos river basin raised the profile of the area's quality of life and health threats, particularly within the media and among environmental lobbying groups ${ }^{3}$, taking into account that $\mathrm{Cr}(\mathrm{VI})$ has been recognized as a substance possibly carcinogenic to humans (Linos et al, 2011; Karagiannis et al., 2015) and that the surface and underground water pollution has been found to contaminate crops (mainly carrots, potatoes and onions) cultivated in the area (Economou-Eliopoulos et al. 2011; Stasinos and Zabetakis, 2013). For example, the river's red water, the result of its high levels of $\mathrm{Cr}(\mathrm{VI})$ gained international attention from a number of US environmental advocacy groups including Friends of the Earth. A particular focus of their coverage was the rising number of cancer incidents in the area. Local communities also expressed their health concerns and organized protests, coalition movements and associations in order to exert pressure on business and particularly government to enforce compliance with environmental laws and regulations. This media attention, however, has also been responsible for the stigmatization of the area which undermines the reputation of the place and has resulted in local producers of agricultural products reporting difficulties in selling their products and trade within the tourism and hospitality sector of the greater area to drop.

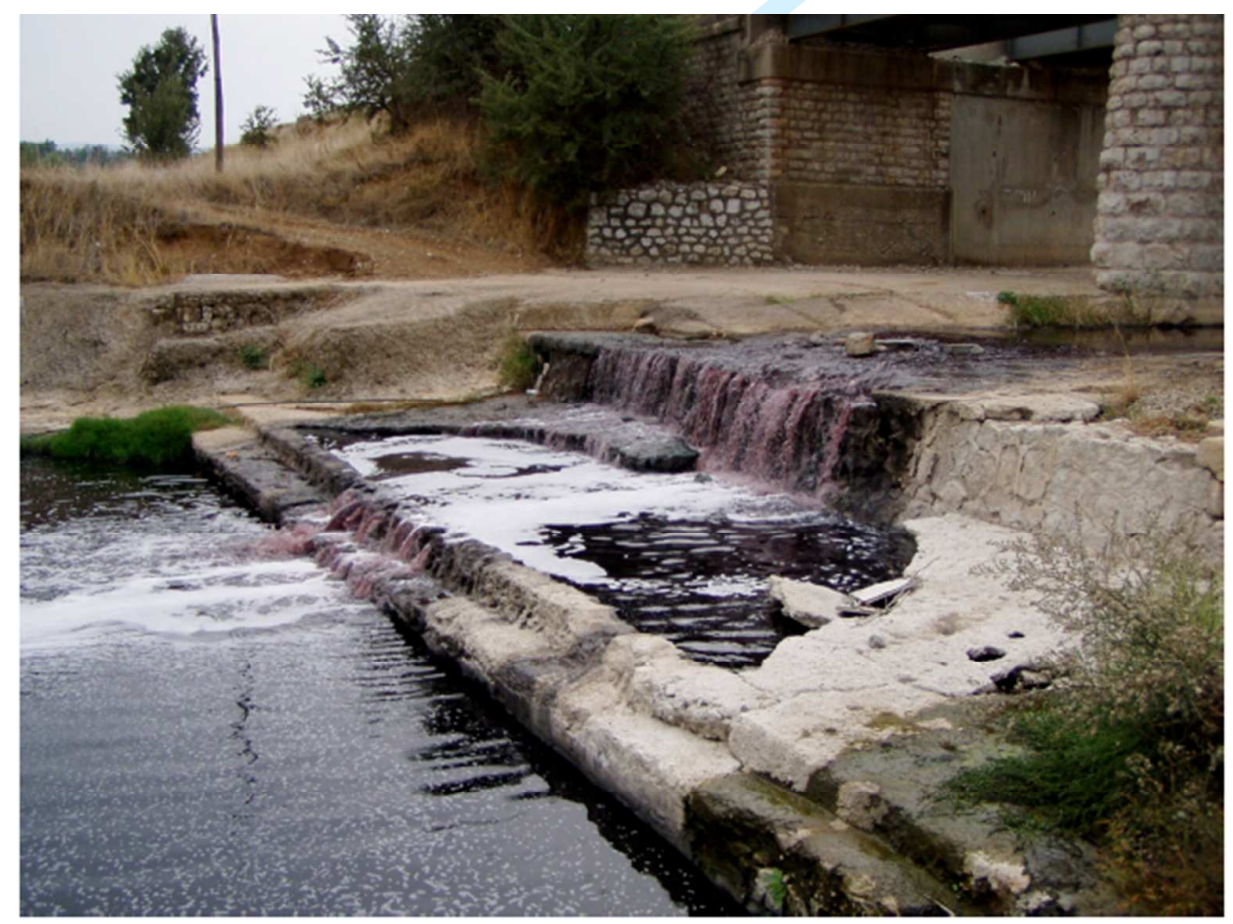

Figure 1: Industrial wastewater polluting Asopos river. Source: http://asopossos.wordpress.com 


\subsection{Data collection}

We focused on small businesses of the tourism and hospitality sector as: (a) these enterprises are directly affected from the environmental degradation of Asopos river and (b) according to Hellenic Statistical Authority data, the vast majority of enterprises $(\sim 99 \%)$ operating in the area are small-scale business entities. Small business owners serve a dual purpose in a settlement as community members and their for-profit organizations are in the unique position to act as hubs of local growth and economic development in the area. Face-to-face interviews using a simple set of questions were selected as the most appropriate approach (Merriam, 2009), in order to better detect small business owners discourse towards the environmental problem of the Asopos river basin. The decision to employ the specific research technique was primarily based on the much-debated nature of the topic investigated and the fact that residents of the affected local communities are extremely wary and skeptical with such surveys due to the negative publicity that the Asopos river has attracted in the past $^{2}$. Between July and October 2014, 41 semi-structured interviews were conducted with owners of small businesses from Oropos, Halkoutsi and Dilesi, settlements in proximity to the river delta (Figure 2; Table 3). These areas depend mainly on tourist activities and, apart from the permanent residents, the local economy relies heavily every summer on seasonal residents and tourist flows.

Table 3. Main descriptors of the interviewed sample

\begin{tabular}{|c|c|c|c|}
\hline Descriptor & n & Descriptor & $\mathbf{n}$ \\
\hline \multicolumn{2}{|l|}{ Gender } & \multicolumn{2}{|l|}{ Years of operation } \\
\hline Male & 27 & Less than 5 years & 4 \\
\hline Female & 14 & 5-10 years & 5 \\
\hline \multicolumn{2}{|l|}{ Age group } & $11-20$ years & 7 \\
\hline$<35$ years & 5 & More than 20 years & 25 \\
\hline $36-60$ years & 29 & \multicolumn{2}{|l|}{ Type of firm } \\
\hline$>60$ years & 7 & Hotel/accommodation & 2 \\
\hline \multicolumn{2}{|c|}{ Family business } & Restaurant/trattoria & 17 \\
\hline Yes & 10 & Take away/quick food & 7 \\
\hline No & 31 & Café/bar & 15 \\
\hline \multicolumn{2}{|c|}{ Number of employees } & \multicolumn{2}{|l|}{ Settlement } \\
\hline $1-4$ & 20 & Oropos & 20 \\
\hline $5-10$ & 16 & Halkoutsi & 11 \\
\hline $10>$ & 5 & Dilesi & 10 \\
\hline
\end{tabular}



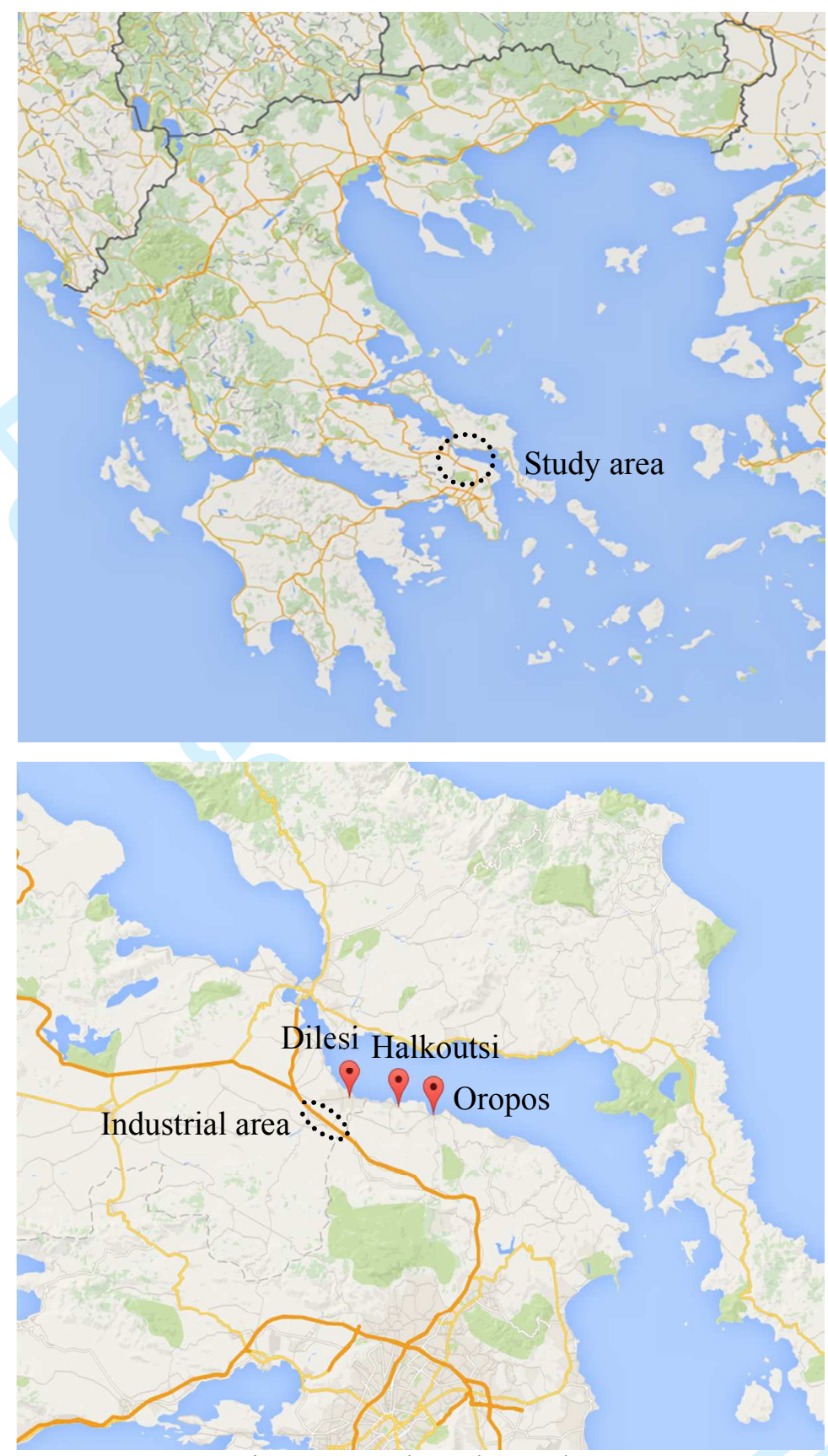

Figures 2 and 3: The study area

\subsection{Description of interviews and data analysis}

An experienced researcher who was familiar with the research area conducted the interviews. The interviews were arranged initially by phone, when the researcher explained to the participant the aims of the study and the expected duration of the interview. The participants were also made aware that the data collected will be anonymous and only used for academic research. The majority of the participants declared that they would prefer that the interview takes place in the premises of their enterprise for practical reasons, before or after the opening hours. We considered that this would facilitate the interview process, as it would make the participants feel more comfortable in a familiar environment and without the presence of customers which would perhaps have an effect on their responses. In addition, the researcher made sure 
that during the interview no other individuals, apart from the interviewee, were present. The average duration of the interviews was 15-40 minutes depending on the level of participation of the interviewee.

The interviews were guided by a set of open-ended, pilot-tested and revised questions to maintain a focused form of dialogue and facilitate meaningful discussion. The interview guide was flexible and adaptive to topics raised by the interviewees in order to better attend their experiences of living close to a polluted river. The order in which the questions were set forth to the interviewees varied according to their engagement and aimed to facilitate the flow of the interview process and stimulate a dialogue. In order to elicit fruitful qualitative data, three broad types of questions were developed, centered around the local environmental conditions, their implications on local economic activity and notions of environmentally responsible business behavior. Place attachment was captured though questions such as "How attached do you feel to Oropos/Halkoutsi/Dilesi?", "Do you feel that Oropos/Halkoutsi/Dilesi is part of you?" or "What does Oropos/Halkoutsi/Dilesi mean to you and your business?". Likewise, perceived place-based stigmatization was gauged by asking the participants "Have you ever experienced discrimination based on the geographical place of your enterprise in your personal or social life, and, if yes, how often?" as well as "Do you feel that your area has a good reputation with people living in adjacent or more distant areas?". In cases where interviewees requested not to tape-record their interviews, extensive notes were taken throughout. Each interview was subsequently transcribed at full length into English and coded using data analysis software. In cases where the interviewees were skeptical regarding the purpose of the survey the researcher reassured them that their personal and business' anonymity is secured and devoted significant time in explaining the aims of the study and how it could benefit the local community by informing current decision-making processes.

After the interviews were completed and transcribed, these were analysed by the principal researcher in collaboration with the other members of the research team. According to the analysis five themes emerged focusing on: awareness and viewpoints on environmental degradation and water quality within the local context, implications on the local economy and the individual enterprise, views on corporate responsibility as well as industrial environmental management and future prospects on the environmental problem of Asopos. These analytic themes were derived through a line-by-line, iterative, process of examination of the transcripts coupled with repeated inspections of the codes assigned to the data in order to frame that information which was relevant in terms of relevance to the study's objectives and the frequency and differentiation in the emphasis and importance attached to various key issues mentioned. Such information was identified as critical in outlining the participants' perspective on the topic and contributed meaningfully in sketching out individual responses of coping with environmental degradation and place-based stigmatization.

A description of the case findings is presented below, followed by a discussion based on the results. Key research findings are illustrated in quotes.

\section{Findings}

The results emerging from the interview data are organized around the key themes regarding the respondents' awareness of the environmental problem, its implications on their small business, their perception and appraisal of corporate responsibility programs implemented by firms operating in the industrial zone along with additional and interlinked issues of concern to be presented in order to contextualize the findings (see Table 4 for an outline of the main findings). 
Awareness of the problem of industrially-induced environmental degradation

With very few exceptions (Table 2), the accounts of interviewed small business owners indicated limited awareness and fragmentary knowledge of the environmental problem the area faces with mostly vague articulations of how pollution occurs and affects the local environment. Unexpectedly, a considerable number of participants were not familiar with the issue of high concentrations of hexavalent chromium or its potential impacts on public health. Only two interviewees provided a detailed account of how the situation of Asopos has been aggravated over the years and demonstrated through their narratives a good knowledge of the problem. Likewise, it was only few accounts that pointed out risks of heavy metal contamination in the food chain (i.e. in crops, fruits-vegetables and/or livestock) and expressed public health concerns referring to the rising cancer incidents in the area of Inofyta and acknowledging that water pollution may be spreading throughout the river basin till its estuaries.

"I don't know many things to tell you on this matter... You refer to the case of Sximatari, don't you? Well, aluminum manufactories, industrial facilities, tanneries, large industries... how is it not possible to turn the river black from all those pollutants? It is a long-lasting problem here but I don't know the current status of the issue. Maybe things have improved by now... I guess the industries there must not operate as uncontrollable as in the past". (Participant 8 , male, 20s)

"To be honest, I have limited knowledge on the issue... The problem of Asopos is taking place for years here and I am not sure it has been resolved yet". (Participant 22 , female, 30s)

"I really don't know... some people here say that they (the industries) keep dumping wastes in the river but I have little knowledge on this matter. Some people say that the problem has been mitigated while others say the pollution goes on and on...". (Participant 37, male, 40s)

A subgroup of respondents strongly emphasized from an early point during the interview that their settlement is not affected by the pollution; they tended to insist through arguments and assertions that the degradation is confined in the areas adjacent to the industrial zone and that the groundwater in their settlements is free from pollutants. The supported that the geographical distance between the industrial area and their settlements is too large for the pollution to spread and pose significant threats. In this respect, they pinpointed that the local municipal water supply poses no risk as the pertaining water reservoirs are flowing far from the susceptible areas of Inofyta and Sximatari. These small business owners acknowledged that the problem of Asopos was existing in the past decades but strongly believed it has nowadays been addressed and the river basin has regained its environmental quality while the pollution is not spreading beyond the industrial area. Some went even further to maintain that since the river's water level and flow have decreased over the years, the levels of pollution have dropped accordingly.

"The river is not flowing anymore (...) it flows few times in the winter months so there is no (pollution) problem. There is no problem, they are creating a problem. The problem may exist in Inofyta but it cannot affect us here. It has been unreasonably magnified". (participant 10, male, 50s)

"The problem of Asopos does not exist anymore; it has come to an end. The river has been cleaned up and well taken care of. I cannot understand why they keep 
bringing this up; it leads nowhere since the industries are applying biological treatment systems and the issue has been resolved" (participant 13, female, 70s, family business)

"This is a local problem of Inofyta (...) the river has extremely low flow, hence, the pollution is not reaching us here". (participant 21 , male, $60 \mathrm{~s}$, family business)

'Who is responsible'?

In an attempt to frame the primary causes that perpetuate the pollution of Asopos, respondents expressed concerns regarding the unsustainability of the current development path in their prefecture. Interviewees stressed a lack of administrative coordination among pertinent public authorities and governmental bodies that undermines the effective decision-making and planning for mitigating environmental pollution. Moreover, a considerable number of respondents emphasized that sanctions and penalties for non-compliance to environmental regulation are in most cases too low as well as ineffective while implemented public policies and the legal justice system are cumbersome and have failed to address the loss of environmental quality in the area.

“(...) All attempts to solve the issue are blocked because geographically the problem spans from Viotia to Attica prefecture and administrative bodies from the latter have no jurisdiction to Viotia's matters. The problem is administrative, too. Thus, it can be addressed only by the central government; not the local authorities, not the municipalities or the prefectural administration. It is only the central government and pertinent ministries which can offer a solution... if there is the respective (political) will to do so". (participant 1 , female, 50s, family business)

In this context, one unifying feature of participants' accounts was that the state was the primary responsible for the environmental problem of Asopos as the design of the industrial zone was viewed as superficial and sketchy with its operation to lack adequate audits from the environmental inspectorates. Respondents also suggested that deep-rooted pathogenies of the Greek public administration and management were evident in the case of Asopos and left no room for efficient policy interventions and control: clientism, favoritism, cronyism. In this respect, many interviewees expressed their skepticism and mistrust with regards to the environmental certifications that many of the companies in the industrial zone are awarded and questioned the professional integrity of verifiers and third-party verification agencies. In a similar vein, increased emphasis was given during their accounts on implicit corruption and bribery perspectives between the industries and public administration officers as well as external environmental auditors/verifiers. Such shadowy transactions, according to the respondents, are a critical point for the perpetuation of the problem.

Many also tended to identify large high profile firms operating in the industrial zone as the major polluters in the area, denoting that many have their biological treatment systems subsidized by European and national funds but only a few actually operate them in full. In this respect, a large group of business owners insisted for stricter sanctions, suggesting that those factories that repeatedly violate environmental regulation should shut down indefinitely. In contrast, they tended to disregard the cumulative impact of small manufacturing enterprises located in the industrial zone area.

"Everything remains unchanged: they keep paying penalties and continue to pollute. I don't think the problem will be over in any time soon since the low 
sanctions and penalties imposed to polluters allow them to retain the same practices and behaviour. A company that gets a $€ 30.000$ fine and makes a million every month pays way too little for the damage it causes...". (Participant 11, male, 30s, family business)

"The situation was wrong all along from the beginning: they 'squeezed' in a small area so many industries of varying activities and under the passiveness and tolerance of the state authorities they left the factory owners unrestrained to throw their wastes in the river... and we are talking about hazardous wastes... toxic wastes...”. (Participant 39, female, 60s)

A number of business owners identified the local community adjacent to the industrial area as passive and slack towards the industrial pollution occurring in their settlements. Others partially justified such stance due to aspects of economic dependency to the industries operating in the area as well as the sliding interest and activism of the locals in the environmental problem of Asopos. Nevertheless, in few accounts it was acknowledged that all local communities near the Asopos basin needed to engage more actively and coordinate appropriate citizen movements for effectively exerting pressure to the state and polluters respectively.

Few small business owners supported that the environmental degradation occurring in the Asopos river basin is a mere communicational topic spotlighted by the national media and local journalists. The accounts of this subgroup of interviewees point out the negative publicity drawn to the river delta serves self-interested purposes of certain journalists as well as 'under-the-counter' transactions with large contractors which have major projects in progress in the other side of Attica. In this respect, one business owner also added that the negative publicity their settlement has a moderating role and reflect a contributing factor to the considerable drop of local property and housing prices.

"Every year the issue of water quality here is turning up in the media and the spotlight...Now, I cannot comment on the extent to which these claims are true but I strongly believe that there are additional reasons for such treatment of Oropos; they always treated Oropos as a marginal area...they want to 'upgrade' and promote others places in Attica because of the large real estate investments that took place there compared to this side of the district". (Participant 19, male, 50s)

\section{Implications on business performance}

More than half of the interviewees criticized that the unjustified - according to their accounts - claims that their settlements are affected by the environmental problem of Asopos tarnishes and brings detraction to their areas. Small business owners from Oropos asserted that the whole area close to the river delta has been segregated and faced an unprecedented (compared to other destinations in the prefecture) decline since the 2000s. They pinpointed that the issue of environmental degradation has been unduly magnified and, combined with a recent increase in the tolls at the highway leading to the study areas, have contributed to a decrease in the number of visitors. In this regard, respondents stressed a loss of the areas' attractiveness which has been also negatively affected by the poor condition of the local road network and the lack of public transportation in the study area. All respondents adopted a defensive stance during the interview, attempting to encounter the negative publicity their area has attracted and sketch out a favorable profile of the area. In many cases, arguments aiming to reduce the attractiveness of other, competing, destinations in the Attica prefecture (in order to bolster local attractiveness) were set forth. Interviewees juxtaposed their area to other places in 
Central Greece in an attempt to present a comparatively more favorable profile for their settlement.

Nevertheless, all small business owners confirmed that the economic downturn of the national economy has severely impacted their business and for most of them it was considered a far more important factor influencing their business than the implications of the pollution of Asopos. The issue of environmental degradation in the river delta was acknowledged as crucial problem of the past decade while the economic crisis that since 2008 has hit Greece was stressed as the overarching problem since the broader area relies primarily on domestic tourists and weekend visitors rather than foreign ones. In an attempt to evaluate the significance of environmental degradation on business performance, several accounts of small business owners ranked the pollution of Asopos third or fourth, after the economic crisis, the recently increased toll way fees and the high fuel prices that avert visitors from this side of Attica in favor of closer destinations. While all these issues had a cumulative impact and turned the river delta area to an under-visited destination, only few perceived environmental degradation as one of the primary problem; it was considered only as a side issue. Eight respondents objected that they had incidents where customers asked specifically for bottled water instead of tap water. In this respect, few owners expressed supporting arguments on the quality of their business services by denoting that their suppliers of vegetables, fruits and/or meat products are not from the areas close to the industrial zone. Nevertheless, in few accounts it was confirmed that health risks in the food chain could exist in the area and that the vegetables grown in the plain of Oropos may pose such threats to public health. Two small business owners asserted that their businesses are thriving and that the Asopos river is not influencing their performance but blamed competing businesses in the area, the civil services and/or community movements for being slack, uncoordinated and not undertaking appropriate actions to exert pressure for resolving the problem.

"The problem lies to all water reserves in the area of the river basin. We avoid getting supplies from local producers, vegetables and other agricultural products". (Participant 5, female, 30s)

"The water here might be clean, but the thing that worries me the most is the vegetables we are buying and using in my business and originate from Viotia; I often think that these products are doing more harm than good...". (Participant 30, male, 40s)

“(...) I've lost customers due to the water issue here; they've told me they can't visit us anymore due to the potential risks of the water here; they don't want to shower or drink from this water". (Participant 14, female, 70s, family business)

"I've had customers that specifically asked for bottled water on their table and not tap water even though I assure them that is perfectly safe; they believe that the whole area here is contaminated". (Participant 23, male, 30s)

A large group of respondents indicated that if they had the necessary financial resources they would relocate their business in a more attractive and not disparaged place as their current location. The same interviewees referred to internationallyrenowned Greek islands, coastal destinations or densely populated urbanized areas as potential relocation points. The options of tax relief or exemption for a period of years as ell as subsidy schemes were pinpointed as policy instruments that would stimulate a potential decision to relocate. Participants with strong bonds with the area were maintaining a counterview; they perceived relocation as a most undesirable scenario 
or the least feasible option primarily due to their attachment to the place and local community. Likewise, few business owners stressed latent costs and underlying risks of relocating as barriers which leave little room for implementing such decision, especially during the current highly turbulent macroeconomic environment.

"I wish I could do this step (of relocating), but there are too many factors to consider; if I have to pay up double or triple of my current annual costs to start a new business in a more attractive place, it is just pointless...At this age and with the current state of the economy you settle for what you've got and simply try to manage to go by". (Participant 26, male, 50s)

"I grew up here, I have my family here, my children got married here...my grand children are here...I can't leave... and go where? Where can I find better? I have my friends, my people, everyone here...". (Participant 14, female, 70s, family business)

\section{Perspectives on responsible business conduct, future prospects and a way forward}

Some interviewees alleged a lack of transparency in environmental audits and an accountability gap from the firms operating in the industrial zone. Aspects of environmental irresponsibility, unethical conduct and stakeholder mismanagement were expressed in an attempt to frame the role of the local industry to the degradation of the local environment. In this respect, very few respondents were familiar with the concept of corporate social responsibility (CSR) but they elaborated that companies should be primarily legally compliant and ensure environmental protection. Few respondents, though unaware of the CSR concept, attempted to frame it around the notions of benign environmental management, good management of human resources and community investments or the 'people vs. profits' bipolar. Others set forth ethical or perspectives of for-profit activities and identified CSR with social consciousness and morality. One interviewee conceived CSR as another word for sustainability and emphasized that the social responsibility of business is to address local considerations so as to contribute to the solution of global problems. According to her narrative, the primary CSR objective of the firms operating in the industrial zone should be the preservation of the carrying capacity of the local environment; all other CSR actions were perceived subordinate and mere 'window-dressing' responses. Likewise, all except five respondents were skeptical and indifferent to the CSR practices and programs promoted by large companies operating in the industrial zone - such actions were viewed as mere communicational and public image activities with no meaningful impact on the long-standing degradation occurring in the area.

Several business owners expressed calls for further and more detailed academic and laboratory research, as current scientific findings (that they are aware of) provide contradicting conclusions on the level and severity of environmental degradation and underlying health risks in the greater area. In contrast, very few were found to be optimistic that the environmental degradation of the Asopos basin will be resolved in the close future. They asserted that the Greek citizen lacks environmental consciousness and responsibility and provided examples in the local setting of such behavior: illegal waste dumping and landfills, poaching and logging. Most respondents supported that the problem is bound to perpetuate and the area will face further decline as neither the pertinent governmental bodies nor the industries in the Asopos basin are showing adequate signs of reversing or even mitigating the impacts of unprocessed waste disposal and emphasized on the notions of injustice and criminal activity that undermines public health in the area. Several also criticized the unsystematic and moderate actions of protest by the local communities as not exerting 
adequate pressure to polluting industries and demonstrating an indifference to the problem and its implications to the local quality of life.

Still, a small number of business owners argued against the current approaches of rigid command and control instruments through sanctions and penalties are not the solution to the problem as over the years proved to be ineffective. According to their opinion they only added fuel to fire by aggravating opposition between community groups and the industries, discrediting the place and not focusing on the actual problem, i.e. the loss of environmental quality. In this respect, these interviewees suggested that new forms of policy making should be devised in addressing the degradation of Asopos basin; policies which would emphasize on participatory approaches and stakeholder engagement as well as voluntary agreements between the state and the industries towards environmental conservation and local sustainability.

"I am well aware of sanctions and environmental fines imposed to these industries, but are these effective? Do they solve the problem? What is needed is cooperation between the governmental bodies and the companies of Asopos. It is solutions what we need, not conflicts (...) I am sure they (i.e. the industries) would opt for a more sustainable solution so that they are not involved in such problems". (Participant 3, male, 40s)

"What I do know is that all these years the problem remains unsolved and responsible for this is the State and its agencies and all other apposite governmental bodies. Is it so hard to gather all industry representatives, local mayors and community members and collectively find a way so that the factories comply, the local communities find their peace and the place does not bear a negative image towards visitors and 'foreigners'. Is it that hard? Opposition lead nowhere...ok, let's put the polluters in jail - do we gain anything from that? ...other than people left without jobs? This why I am telling you: this needs to be worked out beyond fines and convictions". (Participant 28, male, 60s) 


\begin{tabular}{|c|c|}
\hline themes & Key findings \\
\hline $\begin{array}{l}\text { Awareness of environmental } \\
\text { degradation }\end{array}$ & $\begin{array}{l}\text { Fragmentary knowledge of the environmental problem; } \\
\text { Vague articulations of how pollution occurs and misconceptions of } \\
\text { environmental quality; } \\
\text { Local environmental degradation viewed as a mere } \\
\text { communicational topic exacerbated by the media }\end{array}$ \\
\hline $\begin{array}{l}\text { es that } \\
\text { er pollution }\end{array}$ & $\begin{array}{l}\text { Lack of administrative coordination among pertinent public } \\
\text { authorities and governmental bodies; } \\
\text { Low and ineffective monetary sanctions and penalties for } \\
\text { environmental non-compliance; } \\
\text { Cumbersome and ineffective legal justice procedures; } \\
\text { Unsustainable planning of the industrial area; } \\
\text { Inadequate environmental audits from pertinent inspectorate body; } \\
\text { Deep-rooted pathogenies of the Greek public administration } \\
\text { system, i.e. clientism, favoritism, cronyism, corruption; } \\
\text { Skepticism over environmental certification practices; Slack local } \\
\text { community activism towards industrial pollution }\end{array}$ \\
\hline $\begin{array}{l}n \text { the local } \\
\text { he enterprise }\end{array}$ & $\begin{array}{l}\text { Sharp decline of the local economy magnified by the national } \\
\text { financial crisis; } \\
\text { Negative image representations of the area in the media reduces its } \\
\text { attractiveness; } \\
\text { Decrease in the number of visitors and seasonal tourists; Customers } \\
\text { being wary of water pollution; } \\
\text { Strong tendencies to relocate business activities hampered by } \\
\text { financial resources; } \\
\text { Defensive arguments on the quality of local edible products }\end{array}$ \\
\hline $\begin{array}{l}\text { n corporate } \\
\text { industrial } \\
1 \text { management }\end{array}$ & $\begin{array}{l}\text { Arguments framing information asymmetry and accountability gaps } \\
\text { from the firms operating in the industrial zone; } \\
\text { Overemphasis on large industrial firms and underestimation of the } \\
\text { cumulative impact of small manufacturing enterprises in the area; } \\
\text { Aspects of environmental irresponsibility, unethical conduct and } \\
\text { stakeholder mismanagement expressed; } \\
\text { Skepticism and/or indifference over local corporate responsibility } \\
\text { practices; } \\
\text { Corporate responsibility programs viewed as mere } \\
\text { communicational and public image instruments with no material } \\
\text { impacts on local sustainability }\end{array}$ \\
\hline $\begin{array}{l}\text { Future prospects on the } \\
\text { environmental problem of } \\
\text { Asopos }\end{array}$ & $\begin{array}{l}\text { Calls for detailed academic and laboratory research to address } \\
\text { current (contradicting) knowledge on the level and severity of } \\
\text { environmental degradation and potential health risks in the greater } \\
\text { area; } \\
\text { Lack of optimism that the problem will be resolved in the future; } \\
\text { Strong beliefs that the area will face further decline as key players } \\
\text { in the area are not showing adequate attempts to mitigate the } \\
\text { impacts of unprocessed waste disposal; } \\
\text { Arguments against command and control policy-making and in }\end{array}$ \\
\hline
\end{tabular}




\section{Discussion}

Table 4: Key findings derived from the study

The environmental degradation of the Asopos river delta reflects a compelling case of irresponsible disposal of industrial waste together with local economic decline and a lack of sustainable political routes of reinstating community well-being. Longstanding pollution has combined with more recent issues of marginalization to shape a series of diverse reactions and attitudes associated with the degraded setting. Drawing on the typology of responses to stigmatization threats set forth by previous studies (e.g. Wakefield and Elliot, 2000; Castán Broto et al., 2010; Cavazza and Rubichi, 2014) we identify distinct patterns of entrepreneurial accounts in relation to placebased stigma coexisting within the spatial setting. These diverse groups of accounts pertain to responses of denial, indifference and despair.

Deniers (approximately 56\% of the participants) hold very little knowledge of the issues of water contamination due to industrial pollution and expressed strong reluctance to identify environmental degradation within the area their business is located. These respondents manage two- or three-generations-old family businesses and demonstrated narratives of strong place attachment and bonds with the local community. According to their articulations, pollution is non-existent in their community; it is either an issue of the past which is posing no risks of any kind nowadays or it has been overrated and overstated in the public eye (a reaction also reported by Atari et al., 2011). Considerations that the area is unspoiled were bolstered by maintaining the belief that outsiders overemphasize hazards, also pointed out in the studies of Baxter and Lee (2004), Simmons and Walker (2004). Likewise, this is in line with Greenberg and Schneider's (1996) assertion that place attachment, for local people, is sometimes high in areas considered undesirable by outsiders. Deniers' accounts reflected a 'neighborhood halo effect' (Bickerstaff, 2004) and a tendency to 'other' the loss of environmental quality to communities located closest to the industrial zone (Bush et al., 2001). Indeed, deniers stood upon a notion of localized invulnerability to water contamination and related health risks. Potential threats set forth by the researchers during the interviews were inexistent according to these interviewees, with no position to undermine neither their 'core community values' nor the 'reliability' of the place (Wakefield and Elliot, 2000, p.1152). They developed 'othering' arguments on the basis of the geographical distance between their area and the settlements of Inofyta and Sximatari (where maximum pollution incurs) in an attempt to disassociate from environmental degradation, to establish distance thresholds between tainted and non-polluted communities and rank areas across the river basin according to their relative environmental quality. Such proximity effect viewpoints were usually backed up with arguments of perceived essential benefits of the industrial activity to the local economy (e.g. Blowers and Leroy, 1994; Burningham and Thrush, 2004; Hecht, 1998; Williams et al., 1999) and refused to apprehend the industries as sources of harm or threat to community wellbeing (also identified in Baxter and Lee, 2004; Luginaah et al., 2002; Bickerstaff and Walker, 2001). Indeed, prior research has emphasized that people with strong attachment with an area tend to avoid to acknowledge aspects of place despoilment (e.g. Bickerstaff, 2004; Bickerstaff and Walker, 2001; Bonaiuto et al., 1996; Bush et al., 2001; Kaltenborn, 1998; Wakefield et al., 2001). Some of these studies also assert that the presence of industrial activities - as sources of potential stigmatization - can 
strengthen the place attachment of locals as a cognitive response to stigmatization threats and as a coping strategy of retaining the distinctiveness of the area as well as a tangible sense of community cohesion and pride (Burningham and Thrush, 2004; Bush et al., 2001; Hayden, 2000; Simmons and Walker, 2004; Bonaiuto et al., 1996). According to their narratives the national economic crisis is the overarching (or even the sole) problem for the reductions of their enterprise's income, for the decline in their area as well as for collectively having limited options or resources to improve their community's well-being.

Indifferents' responses (representing $32 \%$ of the interviewees) voiced individualistic tendencies, a generalized quiescence and unwillingness to deal with the water contamination of Asopos or to actively understand how the problem is constructed. Their narratives reflected the lowest stocks of social capital, averting from aspects of social organization and actions of local mobilization that would facilitate collective action to address the problem under shared behavioral norms (Putnam, 1993; Levi, 1996). This group of respondents viewed environmental degradation as distant due to the passing of time while shared a rhetoric of apparent tolerance, rationalized and passive attitude to festering issues linked with local stigmatization. They explicitly overlooked potential risks of environmental degradation or the socioeconomic threats of spatial stigma and "turned inwards" (Giddens, 1990, p. 135) by separating their concerns from their everyday life routine and exhibiting a sense of acceptance of the local environmental conditions as unremarkable aspects of everyday life. Having moderate to weak ties to the area they are located, these business owners showed increased disinterest in issues pertaining to the local environment (i.e. the state of Asopos river and potential implications to local areas) and focused through their accounts on issues taking precedence in their lives and business operation than the pollution of Asopos (i.e. the increased tollway prices, the lack of public infrastructures and the generalized downturn of the Greek economy). Such withdrawal into their everyday lives could be seen as an attempt to preserve an ontological security by bracketing out (Beck, 1992; Giddens, 1990) the distressing issue of the polluted river. Indifference was expressed in terms of low levels of concern and agreement to the necessity of environmental restorationprotection and such coping responses to place-based stigma were characterized by 'pragmatic acceptance' (Giddens, 1990; Beck, 1992; Wakefield and Elliott, 2000): a sense of numbness and powerlessness to the issue of industrial pollution and its implications to the area while persistently remaining focused on issues considered 'more important' for their enterprises and lives. This group of business owners seemed to have resigned themselves to the presence of the pollutants in the river and the area's ecosystem, acknowledging that when you live close to an industry it is bound to expect some environmental impacts. As Beck (1987, p. 161) denotes: “(...) in the end, no one wants to know about things they cannot change and which turn their way of life upside-down". Fostering and sustaining a low concern (also found in Baxter and Lee, 2004; Billig, 2006 and Luginaah et al., 2002), these small business owners accept a cost-benefit trade-off between environmental quality and (local) economic prosperity, interpreting employment opportunities and indirect, positive, economic impacts to the local communities closest to the industrial zone as a compensational arrangement of lower environmental quality that mutes local concerns or collective action (e.g. also see Walker et al., 1998; Eyles et al. 2009; DevineWright and Howes, 2010). Such evidence are consistent with those of Dunlap et al. (1993) who noted that direct and indirect economic benefits from local industries partially offset and attenuate health of hazards concerns. In a similar vein, Slovic et al. (2007) also suggest that the positive impact from industrial activities on the local 
communities can be much more than economical and include emotional aspects to financial remuneration that contribute to low risk perception (Baxter, 2009).

Finally, those being despaired (approximately 12\% of interviewees) have weakened or lost attachment to the place they live and operate their enterprise in, providing narratives of entrapment in a landscape with disrupted natural habitats and with minimal potential for economic growth or job security. A collapse of trust and confidence along with cynicism and skepticism (see Irwin et al., 1999) characterize their stance towards the lack of political will (political abandonment), the accountability of industries and the environmental standardization processes that cumulatively contribute to a 'spoiled' identity of the landscape in the eyes of the despaired. Likewise, their narratives indicated strong concerns of uncertainty over the possible effects of pollution on the ecosystem, the food chain, their health, the health of their families and the community. Yet, despite their concerns, their responses revealed an inability and lack of capacity to avert this situation presenting themselves as stakeholders of low salience in the local setting. This group of business owners expressed the strongest desire to relocate their business and leave the area they live in (regardless of the availability of resources to do so) since they found no prospects in the community's future. Abandoning the stigmatized place in hope of 'cleaner' and 'healthier' locations emerged from their responses as the most rational coping response. Albrecht et al. (2007) coin the term solastalgia to exactly describe such distress experienced by residents in cases where they acknowledge that their area is undergoing a negative transition and they draw away from the sense of belonging to the particular area. The 'despaired' group maintained that their area no longer supports their well-being but is associated primarily with negative aspects that carry stigmatization to the land, the local products and mostly the local economic base: tertiary sectors such as the tourism and hospitality. In this respect, previous research suggests that individuals with weak bonds with the place they live in are more likely to identify potentially hazardous aspects of their immediate environment (Bickerstaff and Walker, 2001; Burningham and Thrush, 2004; Wakefield et al., 2001). They acknowledged that the current status quo between industries, governmental authorities and local communities is purely dysfunctional and creates feedback loops that undermine sustainable livelihoods in the broader study area and violate the microsocial contracts of social responsibility among industries and stakeholders. Likewise, they rejected the social legitimacy of industrial activity that led to the environmental degradation of the area, emphasizing on arguments of public unacceptability and environmental injustice, with strong claims for redefining the social responsibility of industries operating in the industrial zone.

\section{Concluding remarks}

Over a period of four decades of industrially induced environmental degradation the Asopos river basin became known as a polluted and degraded area. The findings of this study reveal different layers of concern connected to environmental degradation and spatial stigma that coexist within the local communities of the river's delta. To our knowledge, there are no studies of public attitudes associated with spatial stigmatization in the Greek context; therefore, this work represents a new contribution to the literature, offering evidence from an area where long-standing conflict and public debate on environmental degradation from illicit and waste disposal persistently exist. Additionally, our findings are indicative and reflect longstanding pathogenies of the Greek case: low stocks of social capital (Jones et al., 2008), ineffective environmental policy-making coupled with persistent noncompliance with environmental regulation (Tsaltas and Rodotheatos, 2011; 
Koutoulakis, 2011; Börzel et al., 2012) as well as fragmentary and limited nonfinancial (i.e. environmental and social) accountability by for-profit entities (Evangelinos and Skouloudis, 2014; Skouloudis and Evangelinos, 2014, Skouloudis et al., 2015). Likewise, the findings presented here illustrate similarities with the experiences of communities exposed to other long-standing pollution sources (e.g. Moffatt et al., 1995; Irwin et al., 1999; Bush et al., 2001).

Our findings have relevant implications for both policy design for regional development and managerial practice in the study area (and beyond) in addressing such multifaceted and complex problems that undermine social cohesion and the overall reputation of the area. Policy-making could benefit from attitudinal studies such as ours if better sustainability criteria and management objectives are to be realized in such environmentally-degraded areas. Governmental bodies along with industry members located in the Asopos river basin need to move beyond the operational-technological interventions to reduce environmental externalities and intensify their focus in addressing the social concerns of the local communities and eventually rectify the tarnished reputation of the area. The local community is not in the position to associate the negative environmental impacts with a single or a certain group of industries. This highlights the need to endorse cooperative strategies which involve accountability and reporting mechanisms that will reduce information asymmetry and demonstrate credible commitment in disclosing of environmental information which are material, reliable and accurate in order to decrease speculation and uncertainty over any persistent threats to local communities. Developing trustworthy communication channels that primarily respect the 'right to know' and foster two-way dialogue and learning should primarily guide such efforts under the scope of regaining the social license-to-operate. The role of the apposite state authorities is crucial in acting as intermediaries in maintaining a constructive two-way engagement between the residents and the industry. Moreover, community members should be central in shaping local action plans and their lay views on environmental degradation and aspects of spatial stigmatization could prove to be useful in developing effective participatory decision-making schemes. Such participatory processes should include claims and suggestions by all critical stakeholders and aim at resolving conflicts and issues that aggravate stigmatization. Organizing public meetings or hearings, citizen panels and focus groups could contribute towards that direction, help regain trust as well as public acceptance of the industrial complex, increase community cohesion/consensus and build a shared understanding of responsibility. In this respect, all stakeholders involved in the debate over local environmental planning and conservation need to retain sensitivity to the sustainability concerns of the areas affected by opportunistic business behavior and the underlying negative externalities (Halkos and Evangelinos, 2002).

Nevertheless, sense-making suggests that more rigorous and systematic controls as well as other soft policy instruments (e.g. voluntary agreements) are imperative from the state authorities to avert this situation, guarantee that industrial activities are undertaken appropriately (in an environmentally proactive manner) and ensure that the welfare of the local communities is protected. These actions should be coupled with material compensational-contributory measures that will provide enabling conditions to mitigate the dangers the local residents are exposed to and even regenerate the area's development prospects. Such measures could be the allocation of free-of-charge water supply to all residents of the affected communities, schemes of tax relief or exemption to local enterprises of the tertiary sector (primarily focusing of firms working in the tourism and hospitality industries) or a state fee imposed to all firms operating to the industrial zone, Such fee could be 'reinvested' to improve local 
communities' quality of life and could be defined according to the relative level of environmental nuisance in conjunction with prior failures to comply with the legal requirements for environmental protection.

Our conceptualization of responses to environmental degradation could be explored to other research contexts connected to industrial pollution and related environmental degradation perspectives. The transferability of our findings to other cases and settings of place-based stigmatization is supported by their linkage with existing empirical evidence and the corroboration of relevant theoretical contributions. Indeed, further work on the attitudes of other heavily stigmatized communities could shed light on the extent to which the accounts presented in the study are typical of such places while there is scope to further empirically explore the place-identity bipolar and prompt strategies for spatial planning and local sustainability. In our analysis we concentrated on a certain group of the communities; expanding this selective focus to other residents' groups could reveal additional identity patterns or significant contrasts between members of 'the public'. Moreover, future research could quantitatively assess the loss of welfare and the social impacts in these communities along with the relationship between local social capital and place-based stigma, taking into account in the estimated models socio-demographic factors as well as the geographic proximity and economic dependence to the industrial zone for a more precise investigation of resident's attitudes and coping strategies. Above all, longitudinal empirical work with communities affected by environmental stigmatization from a range of geographical regions as well as settings could provide a better understanding of how the human relationship with a place is (re)negotiated when environmental quality is undermined.

\section{Notes}

1. http://www.ypeka.gr/Default.aspx?tabid=389\&sni $\% 5$ B524\%5D=1561\&language $=$ el-GR (in Greek).

2. http://www.ekathimerini.com/203665/article/ekathimerini/news/high-court-ordersstate-to-tackle-asopos-river-pollution-issue.

3. Kontou (2011) provides a detailed overview of the media attention the environmental problem of Asopos has attracted since the early 1980s.

\section{References}

Achillas, C., C. Vlachokostas, N. Moussiopoulos, G. Banias, G. Kafetzopoulos, and A. Karagiannidis. 2011. "Social acceptance for the development of a waste-toenergy plant in an urban area." Resources, Conservation and Recycling 55: 857-863

Albrecht, G., G.M. Sartore, L. Connor, N. Higginbotham, S. Freeman, and B. Kelly. 2007. "Solastalgia: The distress caused by environmental change." Australian Psychiatry 15: 595-598.

Atari, D., I. Luginaah, and J. Baxter. 2011. "This is the mess that we are living in: Residents everyday life experiences of living in a stigmatized community." GeoJournal 76(5): 483-500.

Baxter, J., and D. Lee 2004. "Understanding expressed low concern and latent concern near a hazardous waste treatment facility." Journal of Risk Research 7(7-8): 705-729.

Baxter, J. 2009. "Risk perception: A quantitative investigation of the insider/outsider dimension of cultural theory and place." Journal of Risk Research 12(6): 771-791.

Beck, U. 1987. "The anthropological shock: Chernobyl and the contours of the Risk Society." Berkeley Journal of Sociology 32: 52-65.

Beck, U. 1992. Risk Society: Towards a New Modernity. London: Sage. 
Bickerstaff, K. 2004. "Risk perception research: socio-cultural perspectives on the public experience of air pollution." Environment International 30(6): 827-840.

Bickerstaff, K., and G. Walker. 2001. "Public understandings of air pollution: the "localization" of environmental risk." Global Environmental Change 11(2): 133145.

Bickerstaff, K., and G. Walker. 2003. "The place(s) of matter: Matter out of place public understandings of air pollution." Progress in Human Geography 27(1): 4567.

Billig, M. 2006. "Is my home my castle? Place attachment, risk perception, and religious faith." Environment and Behavior 38: 248-265.

Blowers, A., and P. Leroy. 1994. "Power, politics and environmental inequality: A theoretical and empirical analysis of the process of 'peripheralisation'." Environmental Politics 3, 197-228.

Bonaiuto, M., G.M. Breakwell, and I. Cano. 1996. "Identity processes and environmental threat: The effects of nationalism and local identity upon perception of beach pollution." Journal of Community \& Applied Social Psychology 6(3): 157175.

Börzel, T.A., T. Hofmann, and D. Panke. 2012. "Caving in or sitting it out? Longitudinal patterns of non-compliance in the European Union." Journal of European Public Policy 19(4), 454-471.

Brown, P., and J. Mikkelsen. 1990. No safe place: Toxic waste, leukaemia and community action. Berkerly: University of California Press.

Burningham, K., and D. Thrush. 2001. 'Rainforests are a long way from here': The environmental concerns of disadvantaged groups. Guildford: University of Surrey.

Burningham, K., and D. Thrush. 2004. "Pollution concerns in context: A comparison of local perceptions of the risks associated with living close to a road and a chemical factory." Journal of Risk Research 7(2):213-232.

Bush, J., S. Moffatt, and C. Dunn. 2001. ""Even the birds round here cough": Stigma, air pollution and health in Teesside." Health \& Place 7(1): 47-56.

Castán Broto, V. 2012. "Exploring the lay/expert divide: The attribution of responsibilities for coal ash pollution in Tuzla, Bosnia and Herzegovina." Local Environment: The International Journal of Justice and Sustainability 17(8): 879895.

Castán Broto, V. 2013. "Employment, environmental pollution and working class life in Tuzla, Bosnia and Herzegovina." Journal of Political Ecology 20(1): 1-13.

Castán Broto, V., K. Burningham, C. Carter, and L. Elghali. 2010. "Stigma and attachment: Performance of identity in an environmentally degraded place." Society and Natural Resources 23(10): 952-968.

Colocousis, C.R. 2012. “"It was tourism repellent, that's what we were spraying": Natural amenities, environmental stigma, and redevelopment in a postindustrial mill town." Sociological Forum 27(3): 756-776.

Devine-Wright, P., and Y. Howes. 2010. "Disruption to place attachment and the protection of restorative environments: A wind energy case study." Journal of Environmental Psychology 30: 271-280.

Dunlap, R., G. Gallup, and A. Gallup. 1993. "Of global concern: Results of a health of the planet survey." Environment 35: 7-39.

Economou-Eliopoulos, M., I. Megremi, and C. Vasilatos. 2011. "Factors controlling the heterogeneous distribution of $\mathrm{Cr}$ (VI) in soil, plants and groundwater: evidence from the Assopos basin, Greece." Chemie der Erde-Geochemistry 71(1): 39-52. 
Edelstein, M.R. 1987. "Toward a Theory of Environmental Stigma." In Public Environments, edited by J. Harvey, and D. Henning, 21-25. Ottawa: Environmental Design Research Association.

Edelstein, M.R. 2004. Contaminated Communities: Coping with Residential Toxic Exposure. Boulder: Westview Press.

Eisenhardt, K. M. 1989. Building theories from case study research. Academy of Management Review 14: 532-550.

Ellerbusch, F. 2006. "Brownfields: Risk, property, and community value." Local Environment 11(5): 559-575.

Erickson, D., C. Reid, L. Nelson, A. O'Shaughnessy, and A. Berube. 2008. The enduring challenge of concentrated poverty in America: case studies from communities across the U.S. Washington: Federal Reserve SystemBrookings Institution.

European Union - EU (2000). Council Directive of 23 October 2002, Establishing a framework for community action in the field of water policy $(2000 / 60 / E C)$. European Official Journal of the European Communities. L327, 22 Dec., 2000.

Evangelinos, K.I., and A. Skouloudis. 2014. "European perspectives on corporate non-financial disclosure: Evidence from the Southeast." International Journal of Disclosure and Governance 11(1): 33-53.

Eyles, J., K. Wilson, L. Mu, S. Keller-Olaman, and S. Elliott. 2009. "What people think about the environment and its relationship to their health: Perceptions of health at different scales of environment in Hamilton, Ontario." Local Environment: The International Journal of Justice and Sustainability 14(10): 981-998.

Giddens, A. 1990. The consequences of modernity. Cambridge: Polity.

Goffman, E. 1963. Stigma: Notes on the management of spoiled identity. Englewood Cliffs: Prentice-Hall.

Gregory, R., J. Flynn, and P. Slovic. 1995. "Technological stigma." American Scientist 83: 220-223.

Greenberg. M.R., and D. Schneider. 1996. Environmentally devastated neighborhoods: Perceptions, policies, and realities. New Jersey: Rutgers University Press.

Halkos, G.E., and K.I. Evangelinos. 2002. "Determinants of environmental management systems standards implementation: Evidence from Greek industry." Business Strategy and the Environment 11(6): 360-375.

Hayden, K. 2000. "Stigma and place: Space, community, and the politics of reputation." Studies in Symbolic Interaction 23: 215-234.

Hecht, G. 1998. The radiance of France: Nuclear power and national identity after World War II. Cambridge: MIT Press.

Howel, D., S. Moffatt, J. Bush, C.E. Dunn, and H. Prince. 2003. "Public views on the links between air pollution and health in Northeast England." Environmental Research 91: 163-171.

Irwin, A., P. Simmons, and G. Walker. 1999. "Faulty environments and risk reasoning: the local understanding of industrial hazards." Environment and Planning A 31: 1311-1326.

Jones, N., C. Malesios, T. Iosifides, and C.M. Sophoulis. 2008. "Social capital in Greece: Measurement and comparative perspectives." South European Society and Politics 13(2): 175-193.

Kaltenborn, B.P. 1998. "Effects of sense of place on responses to environmental impacts: A study among residents in Svalbard in the Norwegian high Arctic." Applied Geography 18: 169-189. 
Karagiannis, D., C. Deliveliotis, E. Papadimitriou, E. Riza, A. Lykou, A. Petralias, A. Papatsoris, and A. Linos. 2015. "Oral exposure to hexavalent chromium through drinking water and urologic morbidity in an industrial area of Greece." Journal of Public Health 23(5): 249-255.

Kasperson, J.X., R.E. Kasperson, N. Pidgeon, and P. Slovic. 2003. "The social amplification of risk: Assessing fifteen years of research and theory." In The social amplification of risk, edited by N. Pidgeon, R.E. Kasperson and P. Slovic, 13-46. Cambridge: Cambridge University Press.

Keene, D.E., and M.B. Padilla. 2014. "Spatial stigma and health inequality." Critical Public Health 24(4): 392-404

Kontou, M. 2011. Public Participation in Environmental Decision-Making Processes: The Asopos case. Athens: European Inter-University Association on Society, Science and Technology.

Koutoulakis, C. 2011. "Environemtal policy in Greece reloaded: Plurality, participation and the sirens of neo-centralism." In Sustainable Politics and the Economic Crisis of the Peripheries: Ireland and Greece. Advances in Ecopolitics, Volume 8, edited by L. Leonard, and I. Botetzagias, 181-200. Bingley: Emerald Publishing.

Laoudi, A., G. Tentes, and D. Damigos. 2011. "Groundwater damage: A cost-based valuation for Asopos River basin." Proceedings of the 3rd International Conference on Environmental Management, Engineering, Planning and Economics (CEMEPE) \& SECOTOX Conference, June 19-24, Skiathos Island, Greece.

Levi, M. 1996. "Social and unsocial capital: A review essay of Robert Putnam's "Making Democracy Work"." Politics and Society 24: 46-55.

Linos, A., A. Petralias, C.A. Christophi, E. Christoforidou, P. Kouroutou, M. Stoltidis, A. Veloudaki, E. Tzala, K.C. Makris, and M.R. Karagas. 2011. "Oral ingestion of hexavalent chromium through drinking water and cancer mortality in an industrial area of Greece-An ecological study." Environmental Health 10(1): 50.

Loizidou, M. 2009. Environmental impact assessment for a central processing unit for the industrial wastewater of Asopos area and the urban wastewater of the municipality of Avlonas. Athens: National Technical University of Athens, School of Chemical Engineering (In Greek).

López-Navarro, M.Á., J. Llorens-Monzonís, V. Tortosa-Edo. 2016. "Residents' behaviour as a function of cognitive appraisals and affective responses toward a petrochemical industrial complex." Journal of Cleaner Production 112(part 2): $1645-1657$.

Luginaah, I.N., S.M. Taylor, S.J. Elliott, and J.D. Eyles. 2002. "Community responses and coping strategies in the vicinity of a petroleum refinery in Oakville, Ontario." Health \& Place 8: 178-190.

Massoura, G. 2008. Pollutant hydrochemistry in Asopos river basin. Athens: Agricultural University of Athens (In Greek).

Merriam S.B. 2009. Qualitative Research: A guide to design and implementation. $3^{\text {rd }}$ edition, John Wiley and Sons, San Francisco.

Ministry of Environment, Planning, and Public Works - MoEPPW. 2003. The law for the management of water resources of Greece, Law N.3199/03. Athens: MoEPPW.

Moffatt, S., P.R. Phillimore, R. Bhopal, and R.C. Foy. 1995. "'If this is what it's doing to our washing, what is it doing to our lungs?' Industrial pollution and public understanding in North-East England." Social Science Medicine 41(6): 883-891.

Moffatt, S., and T. Pless-Mulloli. 2003. "'It wasn't the plague we expected': Parents' perceptions of the health and environmental impact of opencast coal mining." Social Science \& Medicine 57: 437-451. 
Noonan, D.S., D.J. Krupka and B.M. Baden. 2007. Neighborhood dynamics and price effects of superfund site clean-up." Journal of Regional Science 47(4): 665-692.

Putnam, R.D. 1993. "The prosperous community: Social capital and public life." American Prospect 13: 35-42.

Rahardyan, B., T. Matsuto, Y. Kakuta, and N. Tanaka. 2004. "Resident's concerns and attitudes towards Solid Waste Management facilities." Waste Management 24: 437-451.

Satterfield, T.A. 2000. "Risk, remediation and the stigma of a technological accident in an African-American community." Human Ecology Review 7(1): 1-11.

Simmons, P., and G. Walker. 2004. "Living with technological risk: Industrial encroachment on sense of place." In Facility Siting: Risk Power and Identity in Land Use Planning, edited by A. Boholm, and R. Lofstedt. London: Earthscan.

Skouloudis, A., and K. Evangelinos. 2014. "Exogenously driven CSR: Insights from the consultants' perspective." Business Ethics: A European Review 23(3): 258-271.

Skouloudis, A., G.J. Avlonitis, C. Malesios, and K. Evangelinos. 2015. "Priorities and perceptions of corporate social responsibility: Insights from the perspective of Greek business professionals." Management Decision 53(2): 375-401.

Slovic, P., M.L. Finucane, E. Peters, and D.G. MacGregor. 2007. "The affect heuristic." European Journal of Operational Research 177: 1333-1352

Solecki, W.D. 1998. "Local attitudes on regional ecosystem management: A study of New Jersey pinelands residents." Society \& Natural Resources: An International Journal 11(5): 441-463

Stasinos, S., and I. Zabetakis. 2013. "The uptake of nickel and chromium from irrigation water by potatoes, carrots and onions." Ecotoxicology and environmental safety 91: 122-128.

Tentes, G., and D. Damigos. 2012. "The lost value of groundwater: the case of Asopos river basin in Central Greece." Water Resources Management 26:147-164.

Tsaltas, G., and G.M. Rodotheatos. 2011. "Greece and the EU: Promoting the Idea of Sustainable Development - Easy to Plan, Hard to Achieve." In Sustainable Politics and the Economic Crisis of the Peripheries: Ireland and Greece. Advances in Ecopolitics, Volume 8, edited by L. Leonard, and I. Botetzagias, 141-160. Bingley: Emerald Publishing.

Wakefield, S., and S.J. Elliot. 2000. "Environmental risk perception and well-being: Effects of the landfill siting process in two southern Ontario communities." Social Science \& Medicine 50(7-8): 1139-1154.

Wakefield, S., S.J. Elliot, D.C. Cole, and J.D. Eyles. 2001. "Environmental risk and (re)action: air quality, health and civic involvement in an urban industrial neighbourhood." Health and Place 7: 163-177.

Wester-Herber, M. 2004. "Underlying concerns in land-use conflicts - the role of placeidentity in risk perception." Environmental Science \& Policy 7: 109-116.

Williams, B., S. Brown, and M. Greenberg. 1999. "Determinants of trust perceptions among residents surrounding the Savannah River nuclear weapons site." Environment and Behavior 31: 354-371.

Yin R.K. 2003. Case study research: Design and Methods, 3rd edition, Sage Publications, Thousand Oaks. 